\title{
Bargirl Style of Language Choice and Shift: A Tale from the Land of Smile
}

\author{
Hugo Yu-Hsiu Lee \\ National Institute of Development Administration (NIDA), Bangkok, Thailand
}

\begin{abstract}
It is widely recognized that language use, choice and shift have been identified as crucial components to understand the sociolinguistics of mobility, yet relatively few studies have undertaken an analysis of the effects of strategic linguistic change in the workplace, such as bars. In the present pilot study, the researcher surveyed the language choices and shifts of bar girls and beach boys in the capital of Thailand, Bangkok, and the seaside tourist attraction, Pattaya, with a focus on bar English and bar bilingualism or multilingualism. The researcher applied sociolinguistics of mobility to analyze how social meanings are reflected in language changes. The researcher confirmed his findings with previous studies and argued that young women's choices and shifts vis-à-vis language can be best understood in the context of the strategies they adopt in regard to life chances and life style choices.
\end{abstract}

Index Terms - language choice, language shift, language and gender, bar girls, Bangkok, Isaan, Thailand

\section{BACKGROUND}

Strategic language choice and shift do not occur in a vacuum and should not be separated from cultural, economic, financial, social and other contextual factors, which are often focused in analyses. In spite of this, language use, choice and shift of young peasant women of Northeastern (Isaan) Thailand, as well as non-Isaan women from Northern, Central and Southern Thailand, employed in bars associated with life-style choices have received limited empirical attention in Thailand's sociolinguistic literature. The researcher in this present pilot study examined joint effects of mass foreign (sex) tourism and local love (prostitution) industry on behaviors of language changes, with data drawn from bar girls and beach boys in Thailand. Taken together, findings highlighted young women's and men's language choices and shifts associated with their life opportunities in the love industry.

In Thailand, no other modern ethnolinguistic minority and young women's subculture receives as much international media attention as does the young women known as Isaan bargirls. For many years, young females from the Northeastern Thailand have strategically engaged in foreign language learning (English and Western languages) and language shift as a means of socio-economic upper mobility. In light of this phenomenon, the researcher is concerned to address the question of the precise nature of the social meaning of language choice and shift by the members of young Isaan women's speech communities in the discourse used by these women who are involved in Thailand's love industry. The researcher also examines the disparity between Isaan and non-Isaan women's speech and between men's and women's speech as used by love industry workers in Thailand.

\section{SURVEY Sites--BANGKoK AND PATtaya: Thailand’s HeteroseXual Love INDUSTRY}

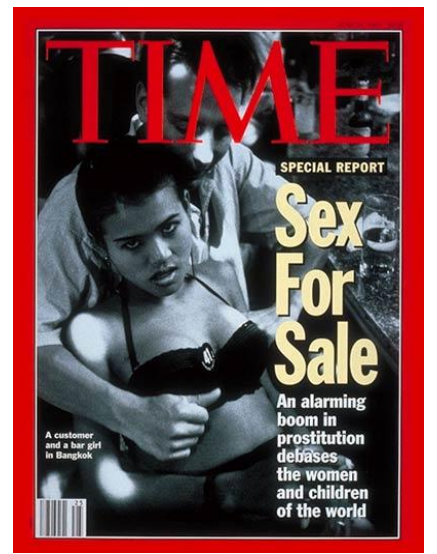

FIGURE 1: Front cover picture of the Time Magazine published in June 21, 1993

(Reporting on world prostitution, a Bangkok bargirl sat in the lap of a Western male tourist)

Service industries are one of the largest commercial sectors of economics in the developed world (Wilson, 2008). 'Service' is seen as a key concept in Thai society (ibid). High qualities of personal and individual services (due largely 
to hospitality management of hotels, resorts, restaurants and massage parlors) have made Thailand successful in the competition of global tourism. However, it is strongly believed that the same key concept of 'service' presumably contributes to the success of Thailand's love industry (Stearn, 2004), as the following quote illustrates (A middle-aged American tourist commented on the high quality of service provided by love-industry workers in Thailand in the following words):

I don't really klthink of them as prostitutes. It's not like that. They are more like a girlfriend-GFE or "girlfriend experience" as it's called. Because it's not just about sex. These girls know how to take care of you and make you feel special. You wake up in the morning, and they're already making your breakfast or ironing your clothes. It is unbelievable!

--Field notes by Pack (2011) on July $7^{\text {th }}, 2007$

It is evidenced that Thailand's high quality of service industries is one of the key elements that attract mass tourism, 'a phenomenon of large-scale packaging of standardized leisure services at fixed prices for sale to mass clients' (Poon, 1993). Motivated by values and interests, tourists seek 'authenticity' and first-hand experiences from what local people have to offer in a foreign country (Przeclawski, 1993).

In this light (high quality of service industries in Thailand), sex is an ever-growing industry in Thailand, which was worth USD \$4 billion in the mid-1990s (Bishop and Robinson, 2002) and worth USD \$15,866,797 from 13.8 million international tourists in 2006 (Woywode, 2007). It is unfortunate but true that poverty has driven young women and men into the love industry (prostitution) in Thailand, particularly with regard to the Bangkok metropolis and the Pattaya seaside city, standing out as global centers of the love (sex) industry for international tourists. Another illustration of Bangkok's image as a global leader of love industries was impressed upon the western world when some stories concerning young Thai girls sold by impoverished parents and rescued by charity workers published in newspapers and magazines with headlines, e.g., 'Voyage to a life of shattered dreams, 'Disneyland for pedophiles,' and 'Pedophiles find paradise on a white beach in Thailand.' The reputation of Bangkok as a hub for sex tourism is also supported by the lyrics of Murray Head's 1984 dance hit "One Night in Bangkok"

One night in Bangkok makes a hard man humble

Not much between despair and ecstasy

One night in Bangkok and the tough guys tumble

Can't be too careful with your company

I can feel the Devil walking next to me

One night in Bangkok and the world's your oyster

The bars are temples but the pearls ain't free

You'll find a God in every golden cloister

And if you're lucky then the God's a she

I can feel an angel sliding up to me

It is widely recognized that no official documentation, accurate statistics and hard empirical data exist on populations of workers involved in the heterosexual love (sex) market in Thailand, due largely to topic sensitivity for Thai academics, the difficulty of definition (e.g., what constitute a love-industry/sex worker), status of young girls and women (Wilson, 2008) and other contextual factors. Albeit substantial (both academic and non-academic) literature exists on bar girls and 'farang' (Thais refer to Westerners as 'farang'), its range and quality are varied from case to case. Western tourists' perspectives are presented on websites as personal diaries and self/life stories by independent writers (e.g., Hutchison, 2002; Stearn, 2004). However, scholarly academic studies can be found in Cohen's (2011) research of Thai tourism: Hill tribes, islands and open-ended prostitution. Parallel to this, Walker and Erlich (1992) reported the relationship between 'Farang' and bar girls in Thailand (also see Lake and Schirbel, 2000; Perve and Robinson, 2007). For a fuller discussion of Thailand's love industry as a 'customized professional services market,' please see Wilson (2008).

As noted above, poverty is largely responsible for Isaan women's engagement in the love industry. "Isaan girls are poor; tourists are rich; I bridged the gap!" (comment by a former Isaan love entrepreneur, cited in Manzanares and Kent, 2006). A principal cause of the phenomenon also lies in gender ideologies stemming from traditional Isaan family values: "My [Isaan] culture holds all women to be not only inferior but expendable," a comment made by Lon, a former love industry worker in Thailand (Manzanares and Kent, 2006). In some Isaan villages, "daughters are cast in the role of caretakers of the family" instead of sons (Brown, 2000). These family values are grounded in Isaan religious beliefs. In Theravada Buddhism, sons earn merit for their parents by simply becoming a monk and staying in a temple for three months to fulfill family duty. However, daughters, particularly first-born daughters, are expected to become the primary income earners and must take care of the needs and welfare of the whole family (Manzanares and Ken, 2006). Therefore, a strong sense of obligation to care for parents is essential to caring members of an Isaan community. Nevertheless, for some Isaan families, at times driven by poverty and at other times driven by greed, there is no limit to the perceived duty to parents of daughters. 


\section{ThaILAND’s LiNGUISTIC ECOLOGY}

Thailand is an ethnically and linguistically diverse State with an estimated 74 languages spoken (Ethnologue, 2005) (For an examination of literacy/orthographies in local languages of Thailand, please see Kosonen, 2008). In respective regions, Northern Thai (Kammeuang), Northeastern Thai (Isaan or Lao), Central Thai (Standard Thai) and Southern Thai (Pak Thai) play key roles as regional languages of wider communication (localization) (Smalley, 1994). However, the Royal Thai government has exalted Central or Standard Thai variety as the national and official language for the use in public domains (e.g., educational institutes and government offices), aimed at strengthening Thailand's national unity (nationalism). Standard Thai is thus the most prestigious language. However, the use of Standard Thai has become a major obstacle in educational achievements and other sectors for not only speakers of other Thai varieties, but also speakers of other ethnolinguistic minorities whose native languages are not related to Thai (Kosonen, 2008). Moreover, increasing globalization has triggered increasing interest in the use of the English language (globalization). This can be seen among love-industry workers. A selective view of theoretical issues and empirical findings relating to the use of the English language can be found in the finding report in this present article. For a more comprehensive treatment of the facts and issues of linguistic diversity and language ecology in Thailand, please see Smalley (1994).

\section{Language Choice, Shift And Vitality}

Gendered language-use-and-choice research has a long history in the field of sociolinguistics/sociology of language/language in society commencing from Gal's (1978) pioneering work in a bilingual town in Austria. There is also a long-standing tradition of language-shift research in the same fields of study. This present section is a selective review of facts and theoretical issues concerning language choice and language shift.

Social factors leading to discrepancies between language choices and shifts have been a central preoccupation and is well documented in sociolinguistic literature as broadly defined (e.g., Fishman, 1964, 1965, 1989, 1991; Giles et al., 1977), as well as developing sociolinguistic norms that account for the extent of language use, choice, maintenance and shift.

In the present article, the researcher uses the term 'language choice' in its most general sense to refer to the daily uses and code choices available in one's repertoire. Attempts to define the terms 'language choice,' 'maintenance and shift' have been shaped by, or in turn have shaped, well-known sociolinguists in our time (e.g., Fishman, 1991; Gal, 1978, 1979). In the light of a variety of perspectives, the author of this article presents their definitions as follows.

First, as extrapolated from the concept of 'linguistic competence' as evinced by an ideal speaker-listener in a homogeneous speech community (Chomsky, 1965) formulated the notion of 'linguistic repertoire' in which a speaker of a language has at his or her disposal a wide range of linguistic variants and develops a register of speech sufficient to undertake a wide range of communicative tasks. Furthermore, Hymes (1974) developed the notion of 'communicative competence,' and initiated research in the fields of the 'ethnography of communication' and 'interactional sociolinguistics'. In Hymes' framework, language choice is referred to as a speaker's linguistic and communicative competence enabling the choice of style and variants with a speaker thereby drawing on his or her linguistic and communicative repertoire as suiting a particular purpose or function. The choice of a speech variety, nonetheless, is by no means a random phenomenon. Rather, the code choice made has to be deliberately selected by the speaker in the light of his or her social and interactional perspective so as to reach a level of satisfactory accommodation to the perceived linguistic situation in the language domain in which current discourse is being undertaken.

A second approach or perspective that guides this article is the distinction between languages in themselves (objective assessment) and attitudes, beliefs, stereotypes and social implications which individuals hold in respect to languages (subjective assessment). Drawing on this distinction in order to frame this research investigation largely stems from the fact that in a class-conscious society, Thais, to a varying degree, are hypersensitive to the socioeconomical implications of accents, varieties (standard versus non-standard), dialects and speech styles as a means of symbolizing the stratification of class, status and prestige. In this vein, we must take into account that dictum that "our language embraces us long before we are defined by any other medium of identity" (Delpit and Dowdy, 2002, xvii). Thus, to a degree, language choice becomes a matter of ideology. The concept of 'language ideologies' is defined as beliefs concerning languages held 'by their users as a rationalization, or justification, of perceived language structure and use' (Silverstein, 1979, P. 193). In this light, the notion of 'language ideologies' is useful in accounting for why minority languages are maintained when their users are oppressed by users of dominant and hegemonic languages (see Woodlard, 1985 for Catalan speakers in Spain). For a crucial introduction to the field of language ideology, see Woodlard, 1998.

Since integral to the discussion of language choices, 'language shift' is another key concept. Gal (1978, 1979, p.1) describes 'language shift' as a process through which 'the habitual use of one language is being replaced by the habitual use of another" at disparate times.

In addition to approaching language choice largely by drawing on the aforementioned concepts, the researcher is concerned to examine the intertwined roles of gender, language choice and shift in the light of work conducted in anthropological linguistics, sociolinguistics and in a number of other fields. It must be acknowledged that the interconnection between gender and language choice has long been recognized and has reached a high level of 
understanding (see Gal, 1978; Mukherjee, 2003; Smith-Hefner, 2009). Thus, there is abundant evidence to show that language choice is often gendered.

On the one hand, a number of previous studies have shown women were more likely to have no or limited proficiency in majority languages in view of lesser access to resources and power (e.g., education) than men in an agricultural (or working class) community. The socioeconomically disadvantaged situation of indigenous women in Latin America has been illustrated by Hill (1987). In these cases in Latin America, women had less access to education and so spoke limited Spanish (a good command of Spanish was essential for these indigenous women in order to be able to access educational and employment opportunities, and would thus enable them to participate in the paid labor force), a state of affairs in contrast to the situation of men. In a similar example, the male elite of the Nugunu or Cameroon villagers in Ombessa, Africa exhibited greater competence in the French language and achieved higher levels of educational attainments than did their female counterparts (Robinson, 1996, pp. 212-213).

On the other hand, previous studies also found that women were constantly searching for a medium that would grant them access to valuable economic and social benefits, opportunities, resources, prestige and symbolic capitals. For instance, in Gal's (1978) pioneering work on the Hungarian-German bilingual town of Oberwart in Austria, a shift away from Hungarian speech to the use of the German language was found to be occurring among peasant women in view of the symbolic linkage between German speech and industrial work that was available to both Hungarian-speaking men and women, albeit being more appealing to the latter than to the former. It appeared that German-speaking factory jobs represented socio-economic advancement, whereas Hungarian-speaking agricultural work was linked to hard-work, low-income, rural, and peasant life. For a fuller treatment of gender and sociolinguistics, see Eckert, 1997 in Coates, 1997 and Coates, 2004.

An area of related interest to this strand of research on young women's social and economical opportunities is studying the effects of urbanization on gendered language choices. Urban centers, by and large, draw poverty-stricken populations from rural areas, due largely to social and economic inducements, such as more job opportunities, better basic infrastructure, and a modern lifestyle (Batibo, 2009, p. 26). In developing countries, it is estimated that 70 million migrants flow annually from rural areas into cities in the search for a better life (Seabrook, 2007). One of the many effects attributed to urbanization is language shift. In her well-regarded article, Smith-Hefner (2009) discussed the phenomenon of language shift from the Javanese (indigenous) language toward the national language of Indonesian emerging in Javanese youth in the nation-state of Indonesia. She went on to argue that in contrast to young men, young women were more likely to shift from Javanese toward the use of Indonesian, which was seen as a means of acquiring the symbolic capital necessary to accommodate their roles in forming part of the new working class.

In connection with this exploration of language choice by young Thai women vis-à-vis relevant concepts, it is to be observed that sociolinguists and linguistic anthropologists refer to the distinctive language usages and uses by speakers of an ethnic group as 'ethnolects' (see definitions of ethnolects in Clyne, 2000; see problems with ethnolects in Jaspers, 2008). An ethnolect approach can better account for the fact that some non-group or out-group members adopt elements of another group's ethnolect in an attempt to bond with members of a different ethnic group, thereby forming crossethnic and multi-ethnic friendship groups. In view of what we know of language contact, it would be only expected that speakers from different ethnic groups would 'converge' in speech by virtue of borrowing linguistic forms typical of members of another ethnic group (see Coronel-Molina and Rodr1'guez-Mondoñedo, 2012 for examples of linguistic convergence in Andes). It can also be argued that the phenomenon of linguistic 'convergence' involves attempts to be understood by others through "symbolic references" to an extent adequate for undertaking communicative acts through utterances and speech acts (e.g., Clark, 1996, cited in Enfield 2009, p. 91). At the same time, this phenomenon is "micro-political" and "coalitional" since designed to ensure that desirable interpersonal relationships are fostered by means of common or shared experiences, including code-switching/mixing with the speech and adopting linguistic features of the discourse of interlocutors from another ethnic group (Enfield, 2009. p. 91).

Across many studies that examine gendered language choice and shift of all the above-mentioned concepts and constructs, it has emerged that a perspective that is useful in the analysis of Thailand's diglossia and linguistic repertoire and, at the same time, frames this study stems from 'ethnolinguistic vitality' theory (formulated by Giles et al., 1977; Landry and Bourhis, 1997, P. 32). It is defined as what 'makes a group likely to behave as a distinctive and active collective entity in intergroup situations.' In this vein, the political status of languages recognized by the state (e.g., institutional support), demographics, economic considerations (e.g., medium of communication in commerce) and cultural capital are means of 'objectively' measuring the continued linguistic existence of an ethnic group's mother tongues, native languages and inherited languages within a linguistically heterogeneous society. By contrast, members of an ethnic group are asked to subjectively rate and predict the present and inferred future vitality of their languages as 'subjective' measures to account for the degree of ethnolinguistic vitality of their languages (e.g., see Draper 2004, 2010 for an assessment of the ethnolinguistic vitality of Isaan Thai).

\section{Methodology}

Below, the researcher gives a brief summer of research questions, sites, participants, measuring instruments, procedures and analysis. The researcher employed multiple methods of data collection and analysis over the period of field-site investigation. 
The relationship between language use, language choice and language shift has been of increasing interest over the past half quarter century, whereas the role of workplace or life choice in these fields of sociolinguistic literature (particularly in Thailand) remains significantly under-explored. Thus, the research questions pursued are as follows:

(i) What is the extent to which the ethnolinguistic vitality of the Isaan speech variety can be maintained in Thailand's love industry?

(ii) How can we describe the language-use-and-choice patterns observed in bars of Thai love-industry workers?

(iii) How does the love industry appear to contribute to its workers' English language learning?

(iv) What are social meanings behind language use, choice and shift of Thai love-industry workers?

The study investigated language-choice-and-shift behaviors of love-industry (sex) workers in Bangkok, the capital of Thailand, and Pattaya. Bangkok is the largest city in the country, whereby more than a quarter of the population resides. Moreover, the majority of the population is monolingual, with an estimate of $90 \%$ of the Standard Thai speakers. Pattaya has similarities to major metropolitan tourist cities in Thailand, with a growing economy and as a regional tourist center has a great amount of tourists from North America, Western Europe, Middle East and Eastern Asia.

In this pilot study, a criterion-sampling is adopted. Thai love-industry workers can generally be considered to be one of three main types (Thai bar (sex) workers fall into three main categories, defined in this study):

(a) Sample 1 (Female, N=200): Northeastern (Isaan) bar girls

(b) Sample 2 (Female, N=50): Non-Isaan bar girls from Northern, Central and Southern regions of Thailand

(c) Sample 3 (Male, $\mathrm{N}=50$ ): Thai men/beach boys

The average (mean) of participants was 25 years.

Building on an analysis of existing attempts to measure language-choice-and-shift behaviors, the researcher adopted a triangulation with data stemming from three disparate sources: questionnaire surveys, interviews and observations. With regard to instruments, participants were measured by 5-point scale Likert-type questionnaire items. Individual preliminary interviews, focus-group interviews and retrospective interviews were accompanied by non-participant observations and were carried out at the beginning-point and mid-point of the course of research, prior to triangulation of data at the end of the course of the research. To draw findings from data, a constant comparison method was applied.

\section{RESULTS}

Results were taken concurrently (by means of triangulation) from questionnaire, observation or interviews.

\section{A. Isaan Woman Sample}

Answers to Research Question (i): What is the extent to which the ethnolinguistic vitality of the Isaan speech variety can be maintained in Thailand's love industry?

TABLE 1:

A MINIMAL EVALUATION OF THE ETHNOLINGUISTIC VITALITY OF THE ISAAN SPEECH IN HOME VILLAGES VS. LOVE-INDUSTRY WORK DOMAINS

\begin{tabular}{lll}
\hline \hline EV of Isaan & $\begin{array}{l}\text { Home Villages } \\
\text { (Northeastern Thailand) }\end{array}$ & $\begin{array}{l}\text { Work Domains } \\
\text { (Bars) }\end{array}$ \\
\hline & $\begin{array}{l}\text { Getting Weaker } \\
\text { (Gradual shift to Standard Thai use in the } \\
\text { younger generations) }\end{array}$ & $\begin{array}{l}\text { Getting Stronger } \\
\text { (Maintained) }\end{array}$ \\
\hline
\end{tabular}

The love industry has created the largest Isaan speech community outside home villages in Northeastern Thailand (It should be also noted that Phuket, another tourist site in Thailand, is the second largest Isaan speech community outside the Isaan home region), has tremendously contributed to the language maintenance of the Isaan speech. Consistent with Woolard's (1985) observation of an alternative linguistic market that challenges a single linguistic hierarchy, it is argued that while the Isaan vernacular in its home region suffers language shift away from the Isaan variety toward Standard Thai speech (Draper, 2004, 2010), the ethnolinguistic vitality of Isaan is relatively strong and symbolically opposes the dominant and legitimized Standard Thai code in the seaside town (Pattaya) and work domains (bars) in Bangkok Metropolis, largely due to the fact that Isaan women constitute the vast majority of bargirls. By the same token, while the Isaan young women's speech communities studied are not only subject to the constant lose of population (e.g., some married Western tourists and others moved or returned to Isaan villages to invest in small business), they are still also subject to the constant influx of novice Isaan women coming to work in the love industry, as well as increasingly fellow non-Isaan co-workers' adoption of Isaan ethnolects (The researcher further comments on this at length.).

Moreover, numerous avenues of investigation converge on the fact that the maintenance and ethnolinguistic vitality of Isaan vernacular is relatively strong in the two tourist sites studied. Among these are the linguistic normalization theory (Vallverdú, 1985), the ethnolinguistic vitality theory (Giles et al., 1977), the ethnolect theory (Clyne, 2000) and the discursive practice theory (Young, 2009; Hall, 2009). By means of the establishment of normative usages and uses in work domains and elsewhere, along with the extension of its multifaceted utility in socio-economical and sociocultural life, the notion of linguistic normalization propounded by Vallverdú (1985) largely accounts for the fact that Isaan vernacular has been continually gaining ground in the battle with the Standard Thai variety and the English 
speech for fuller normalization in the seaside resort of Pattaya and work domains (bars) in Bangkok Metropolis studied by the researcher. In the same vein, the formation of demographic (given the vast majority of love industry workers are Isaan) and economical (the language adopted in commercial activities on streets and in the love industry) capital (Giles et al., 1977) largely account for the strong ethnolinguistic vitality of Isaan vernacular in this seaside town. The Isaan vernacular, albeit discriminated against, oppressed, stigmatized and stereotyped in official domains (e.g., workplaces, educational institutions and the mass media) (Draper, 2010, P. 135), is warmly welcomed and embraced in the seaside town (Pattaya) studied, given that locals and tourism-oriented business sectors rely heavily on Isaan women to attract foreign male tourists. This confirms Mandanares and Kent's (2006, P. 46) observation that since Isaan is the lingua franca in bars non-Isaan women see a need to learn the Isaan vernacular to understand what the majority of Isaan women in the bars are discussing at any one time (Manzanares and Ken, 2006, P. 46). Moreover, for some non-Isaan women part of becoming love-industry workers involved a shift in language choice and use away from Northern, Central and Standard Thai varieties to the adoption of Isaan ethnolects in their work domains. Illuminating in this connection is the fact that novice non-Isaan intakes were instructed by their seniors with respect to acquirable skills and manners (e.g., Western-style make-up) deemed to attract male Western tourists. In the light of the discursive practice approach pursued by Hall (2011) and Young (2009), the researcher also addresses how members of the non-Isaan women's groups learn and develop the competences needed in the love industry, while honing their newly acquired linguistic and behavioral capacities under the guidance of more experienced Isaan participants in the love industry (Vygotsky, 1978) through being socialized into an Isaan-style elder sibling/younger sibling hierarchy (see Howard 2007, PP. 206-208).

Answers to Research Question (ii): How can we describe the language-use-and-choice patterns observed in bars of Thai love-industry workers?

TABLE 2:

LANGUAGE-USE PATTERNS OF THE ISAAN WOMEN STUDIED

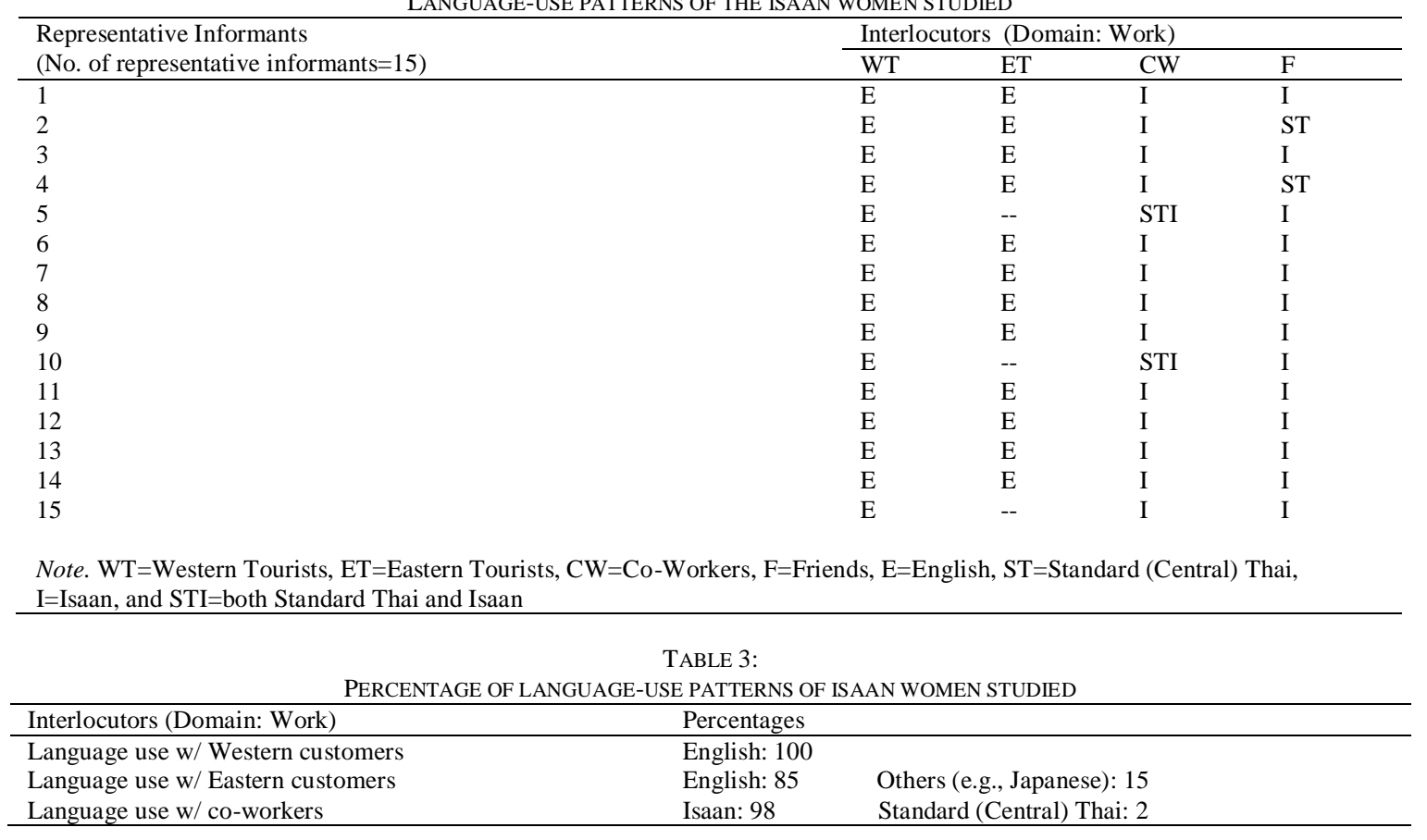

Among the three groups studied, the Isaan women's group as a whole exhibits a higher attainment of English speech. Although the Isaan variety is maintained in the work domains of the two sites studied, the Isaan women's group is more likely to embrace English speech, thereby explaining the fact that a relatively small number of Isaan women shift toward English speech away from the Isaan speech. However, at the same time, the non-Isaan women's group as a whole exhibits a habitual use of the Isaan vernacular in their work domains, accounting for their slow but steady shift toward the Isaan speech away from their Thai varieties. In addition, the Isaan women's group markedly exhibits a gradual shift in progress toward the English speech. The same progress, nevertheless, does not appear to be occurring among most members in the non-Isaan women's group and almost never does it occur in the Thai men's group (the researcher comments further on this with fuller treatment in the following sub-sections).

Answers to Research Question (iii): How does the love industry appear to contribute to its workers' English language learning? 


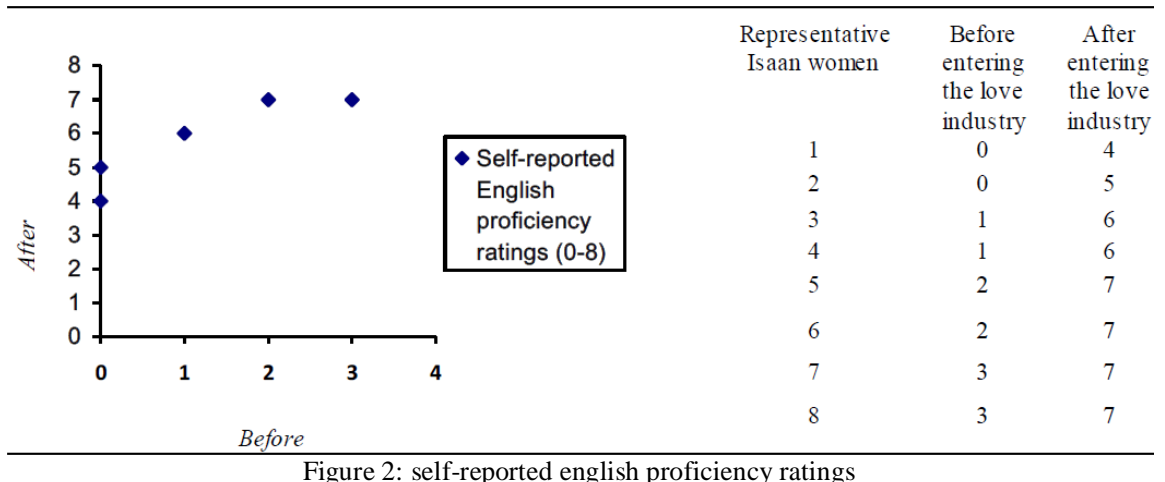

Figure 2: self-reported english proficiency ratings

Claimed by isaan women's group studied

Note. Key to numbers indicating language proficiency

$0=$ no proficiency, 1 =begin to understand and grasp some words and phrases, 2 =beginning level,

3 =beginning-intermediate level, $4=$ intermediate level, $5=$ intermediate-advanced level, $6=$ advanced level/good command, $7=$ fluent/native-like, $8=$ native proficiency

In the view of some of the Isaan women studied, their shift away from the Isaan vernacular to the habitual use of the English speech is a means of coping with class struggle (this is not the Marxist notion of "class struggle") (they are considered third class citizens by the rest of Thailand, due largely to the region of their birth), gendered discrimination (they are second class in their villages, due largely to their gender by birth) and are impoverished. Thus, the shift is inextricably connected with enhancing face and life chances (capability of conversing in English with Western tourists is a means of increasing income).

Thus far, this study confirms the findings of numerous previous studies. Consistent with Smith-Hefner (2009, P. 72) (Indonesian women's shift away from the indigenous-Javanese speech to the national language of Indonesian is seen as contesting conventional gendered roles imposed to them), some Isaan women's gradual shift away from the Isaan vernacular to the habitual use of the English speech is a means whereby the gender ideology stemming from traditional Isaan family values can be resisted. Furthermore, in the just mentioned article (ibid.), young women in Java were particularly drawn into urban centers (e.g., Yogyakarta) because of enhanced possibilities for social mobility. Their shift away from the formal styles of Javanese to the less formal Indonesian, the national language, was linked to their newly acquired middle-class status (ibid.). It is argued that there are similar dynamics at work vis-à-vis the target population studied in this article. Possibilities of social mobility (from rural lower-class backgrounds to urban middle-class 'entrepreneurs') draw young Isaan peasant women to urban centers. Their shift away from the Isaan vernacular to the English speech is linked to their socio-economic mobility, given English is the medium of communication used in their concomitant shift to love entrepreneurship.

Data also suggest that a gradual shift toward the English speech is seen as a strategic plan pertaining to possibilities of life-style enhancement (e.g., "secret dreams of moving to Europe [or North America or Australia], having a prosperous new life" by marrying one of the Western male tourists was revealed by Lon, a former love-industry workers in Thailand, cited in Manzanares and Kent, 2006, P. 105). Consistent with Gal's classic study undertaken in Oberwart, Austria, in 1978, data in her article suggest that "women's speech choices must be explained within the context of their social position, their strategic life choices" (Gal, 1978, P. 15).

In short, the view that women tend to have more to gain than men in the love industry of Thailand is suggested by the data in this study. Among the informants, Isaan women, contrasted to non-Isaan women, are the single greatest group of beneficiaries in the love industry of Thailand. The Isaan women studied choose to learn English, meet with male Western tourists and become love entrepreneurs to financially support themselves and their families. For some, they want a better quality of life and a brighter future after saving enough money to invest a small business in their home villages. At the same time, being fluent in English also means that they may be able to move to America, Europe or other western or first-world countries for an enhanced lifestyle.

Answers to Research Question (iv): What are social meanings behind language use, choice and shift of Thai loveindustry workers? With respect to Isaan women's speech community under consideration, their language choice is a means of poverty reduction and social and economic mobility, and language shift is a means of resistance against gender ideologies and lifestyle enhancement.

\section{B. Non-Isaan Woman Sample}

Answers to Research Question (i): What is the extent to which the ethnolinguistic vitality of the Isaan speech variety can be maintained in Thailand's love industry? As is evidenced by the empirical data that certain changes (convergence with Isaan speech styles and shifts away from the native speech to the habitual use of the Isaan vernacular) in progress emerged in the non-Isaan women's group are not in progress in the Thai men's group. It is striking to see that the nonIsaan women's group studied as a whole demonstrates a greater use of the Isaan vernacular. This is a surprising result, given Standard (Central) Thai is considered the most prestigious variant (ranked No. 1) and a standard speech of the 
pan-Thai language family spoken in Thailand, followed by Northern (ranked No. 2) and Southern accents (ranked No. 3), and then Northeastern Isaan (ranked No. 4) (see Chanyam, 2002; Draper, 2010, pp. 135-136).

Self-reported
$\begin{aligned} & \text { English } \\ & \text { proficiency } \\ & \text { ratings (0-8) }\end{aligned}$

$0=$ no proficiency, $1=$ begin to understand and grasp some words and phrases, $2=$ beginning level, $3=$ beginning-intermediate level, $4=$ intermediate level, $5=$ intermediate-advanced level, $6=$ advanced level/good command, $7=$ fluent/native-like, $8=$ native proficiency

Answers to Research Question (ii): How can we describe the language-use-and-choice patterns observed in bars of Thai love-industry workers? Not surprisingly, the use of the English language, the Isaan vernacular and the Standard Thai variety are alternated (code-switch) in bars by non-Isaan female workers.

TABLE 4:

LANGUAGE-USE PATTERNS OF NON-ISAAN WOMEN STUDIED

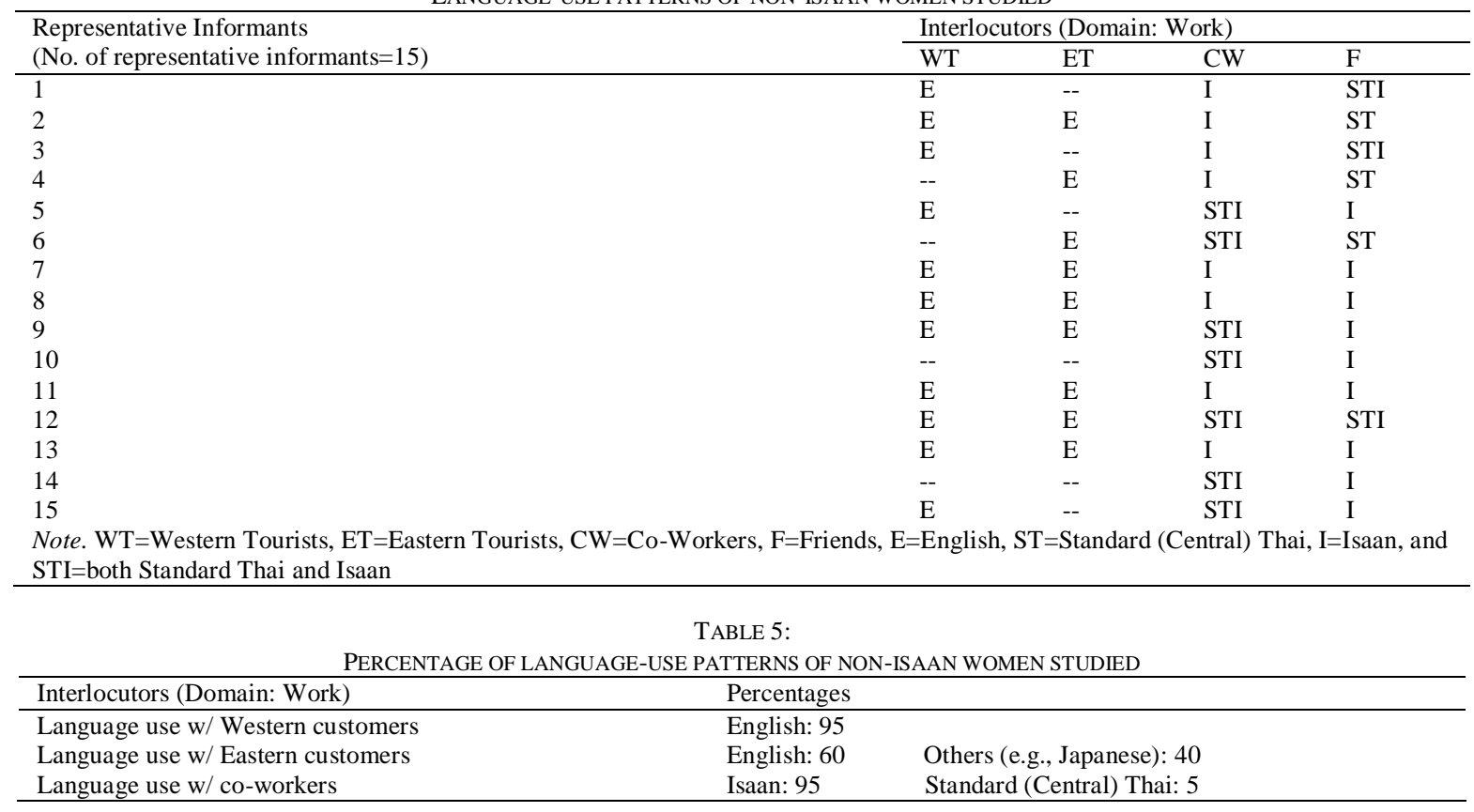

Answers to Research Question (iii): How does the love industry appear to contribute to its workers' English language learning? From the data, a recurrent finding is that the use of the English language among non-Isaan women employed in bars is increasing. 


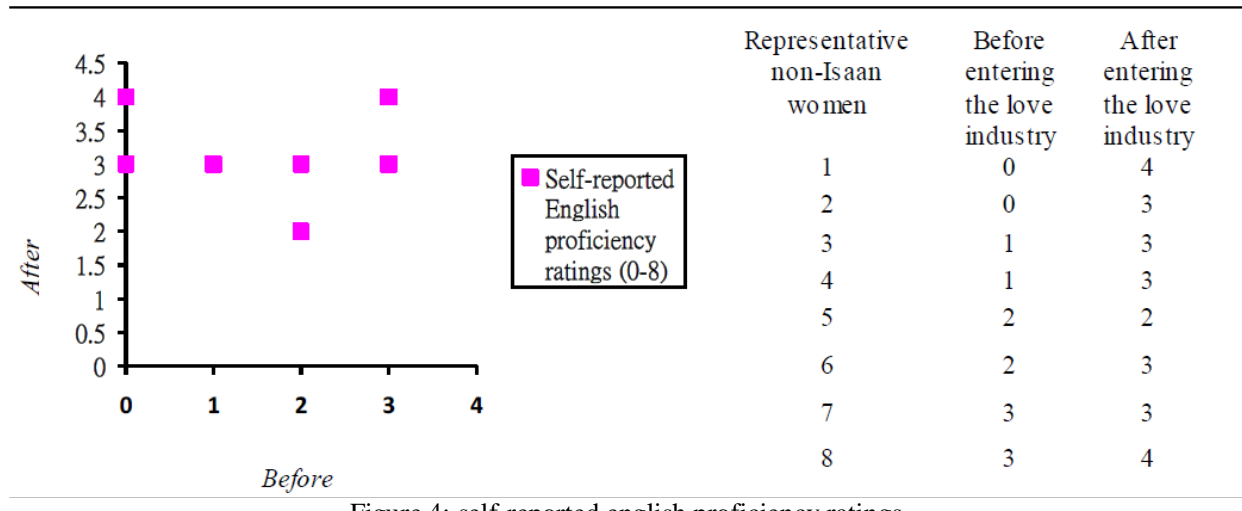

Figure 4: self-reported english proficiency ratings

Claimed by non-isaan women's group studied

Note. Key to numbers indicating language proficiency

$0=$ no proficiency, $1=$ begin to understand and grasp some words and phrases, $2=$ beginning level, $3=$ beginning-intermediate level, $4=$ intermediate level, $5=$ intermediate-advanced level, $6=$ advanced level/good command, $7=$ fluent/native-like, $8=$ native proficiency

Answers to Research Question (iv): What are social meanings behind language use, choice and shift of Thai loveindustry workers? In regard to the non-Isaan women employed in bars, ethnolect convergence and language choice are means of participation in discursive practice (with the majority of Isaan-speaking co-workers) in their workplace (bar language domains).

\section{Thai Man Sample}

The less favored role Thai men (contrasted to women engaged in the same activity) play in the love industry largely account for their relatively monolingual Thai speech and lower English proficiency.

Answers to Research Question (ii): How can we describe the language-use-and-choice patterns observed in bars of Thai love-industry workers? The pattern of results seen in the Thai man sample is also not surprising to find that they are relatively monolingual Thai speakers, despite some can converse in the basic English language with Western tourists.

TABLE 6:

LANGUAGE-USE PATTERNS AMONG THAI MEN STUDIED

\begin{tabular}{lllll}
\hline Representative Informants & \multicolumn{3}{l}{ Interlocutors (Domain: Work) } \\
\cline { 2 - 5 } (No. of representative informants=15) & WT & ET & CW & F \\
\hline 1 & -- & -- & -- & ST \\
2 & -- & -- & ST & ST \\
3 & -- & -- & ST & ST \\
4 & -- & E & ST & ST \\
5 & -- & -- & ST & ST \\
6 & -- & E & ST & ST \\
7 & E & E & I & I \\
8 & E & -- & I & I \\
9 & -- & -- & I & ST \\
10 & -- & -- & ST & ST \\
11 & E & E & -- & ST \\
12 & E & -- & -- & ST \\
13 & E & -- & - & ST \\
15 & -- & -- & -- & ST
\end{tabular}

Note. WT=Western Tourists, ET=Eastern Tourists, $\mathrm{CW}=\mathrm{Co}-$ Workers, F=Friends, E=English, ST=Standard (Central) Thai, $\mathrm{I}=\mathrm{Isaan}$, and STI=both Standard Thai and Isaan

TABLE 7:

PERCENTAGE OF LANGUAGE-USE PATTERNS AMONG THAI MEN STUDIED

\begin{tabular}{lll}
\hline \hline Interlocutors (Domain: Work) & Percentages & \\
\hline Language use w/ Western customers & English: 60 & No active communication: 40 \\
Language use w/ Eastern customers & English: 40 & Others (e.g., Japanese): 10 \\
Language use w/ co-workers & Isaan: 30 & Standard (Central) Thai: 70 \\
\hline
\end{tabular}

Answers to Research Question (iii): How does the love industry appear to contribute to its workers' English language learning? It seems that Thai men employed in the love industry are less able to learn the English language than their female counterparts. 


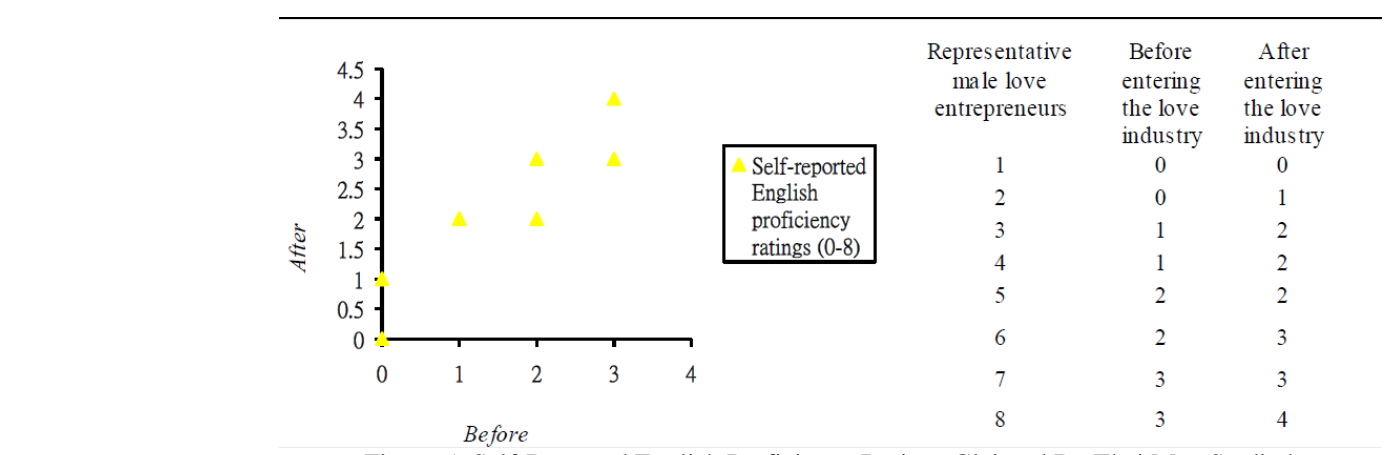

Figure 5: Self-Reported English Proficiency Ratings Claimed By Thai Men Studied Note. Key to numbers indicating language proficiency

$0=$ no proficiency, $1=$ begin to understand and grasp some words and phrases, $2=$ beginning level, $3=$ beginning-intermediate level, $4=$ intermediate level, 5=intermediate-advanced level, $6=$ advanced level/good command, $7=$ fluent $/$ native-like, $8=$ native proficiency

\section{DISCUSSION AND CONCLUDING REMARK}

As discussed earlier, previous research of the use of language by women often showed that their language choice and shift were notably associated with potentially bettering the conditions of life and life chances, such as poverty reduction, social and economic mobility (from the margins of society to the new middle class) (Gal, 1978; Smith-Hefner 2009), resistance against public ideologies (Gagné, 2008) and improved lifestyles. The present findings extend the results of these previous investigations by indicating that women of disparate ethnic groups (Isaan and non-Isaan) engaged in the same activity in the same industry had different degrees of association with the same languages (in this case, English and Isaan), while discrepancies in associations led to different social and economical outcomes.

Summary of Answers to Research Question (ii): How can we describe the language-use-and-choice patterns observed in bars of Thai love-industry workers? There exists hard evidence that the Isaan speech is well-maintained in bars of Bangkok and Pattaya. Further, illustrations of the disparate results of language-use-and-choice patterns among Isaan women, non-Isaan women and Thai men studied can be seen in the comparison among Table 8, Table 9 and Figure 6.

TABLE 8:

ETHNOLECT CONVERGENCE AMONG ISAAN AND NON-ISAAN WOMEN STUDIED

\begin{tabular}{|c|c|c|c|c|c|}
\hline Media & Participants & Interlocutors & Domains & Sites & Converging $w /$ \\
\hline \multirow[t]{8}{*}{ Speaking } & Isaan & Co-workers and & Work & $\mathrm{B}$ & ST/E \\
\hline & & Customers & & $\mathrm{P}$ & $\mathrm{E}$ \\
\hline & & Others & Non-Work & B & ST \\
\hline & & & & $\mathrm{P}$ & I \\
\hline & Non-Isaan & Co-workers and & Work & B & $\mathrm{I} / \mathrm{ST} / \mathrm{E}$ \\
\hline & & Customers & & $\mathrm{P}$ & $\mathrm{I} / \mathrm{E}$ \\
\hline & & Others & Non-Work & B & ST \\
\hline & & & & $\mathrm{P}$ & $\mathrm{I} / \mathrm{E}$ \\
\hline
\end{tabular}

Note. $\mathrm{B}=$ Bangkok, $\mathrm{P}=$ Pattaya, E=English, $\mathrm{ST}=$ Standard (Central) Thai Variety, I=Isaan Thai Variety

TABLE 9:

MEAN LANGUAGE-USE SCORES

\begin{tabular}{llll}
\hline \hline$M$ & $\begin{array}{l}\text { Isaan women } \\
(n=100)\end{array}$ & Non-Isaan women $(n=50)$ & $\begin{array}{l}\text { Men } \\
(n=50)\end{array}$ \\
\hline English & 93 & 78 & 50 \\
Isaan & 98 & 95 & 30 \\
Standard (Central) Thai & 2 & 5 & 70 \\
\hline
\end{tabular}
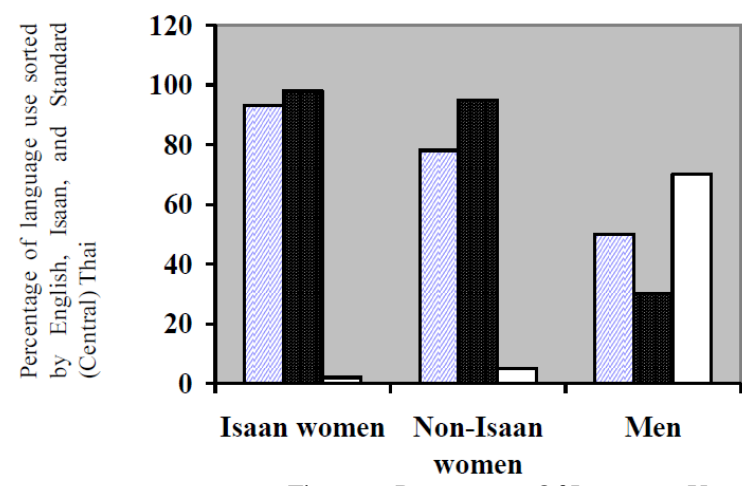

Figure 6: Percentages Of Language Use 
Taken together, this article has reexamined that young women do not merely simply choose, or shift to or from, a language out of their linguistic and communicative repertories; rather their linguistic strategies are better understood by taking into consideration their life strategies and possible life chances (Gal 1978: 15; Smith-Hefner 2009). This article demonstrates that the choice and shift of languages have a much wider-spread attraction for young Isaan and non-Isaan women than Thai men engaged in the activities of the love industry, as they seek to become members of a new entrepreneur class in urban centers in contradistinction to their former stigmatized peasant status in rural areas. Further, Isaan women take fuller advantage of these new social and economic opportunities than non-Isaan women and Thai men involved in the same industry.

\section{ACKNOWLEDGEMENT}

The photo credit for the figure 1 should go to the photographer who took the front cover picture for the Time Magazine (June 21 $1^{\text {st }} 1993$ edition). Furthermore, this article stems from a larger research project funded by the Research Center at the National Institute of Development Administration (NIDA) in Thailand.

\section{REFERENCES}

[1] Batibo, H. M. (2009). Poverty as a crucial factor in language maintenance and language death: Case studies from Africa. In Harbert, W., McConnell-Ginet, S., Miller, A., \& Whitman, J. P. (eds.). Language and Poverty, p. 23-36. Bristol: Multilingual Matters.

[2] Bishop, R., \& L.S. Robinson. (2002). Travellers' tails: Sex diaries of tourists returning from Thailand. In S. Thorbek and B. Pattanaik (eds.). Transnational Prostitution, pp. 13-23. London: Zed Books.

[3] Brown, L. (2000). Sex Slaves: The Trafficking of Women in Asia. London, UK: Virago Press.

[4] Chanyam, N. (2002). A study of language attitude toward Thai dialects and their speakers: A case study of four campuses of Rajamangala Institute of Technology. M.A. Thesis, The Faculty of Graduate Studies, Mahidol University, Thailand.

[5] Chomsky, N. (1965). Aspects of the Theory of Syntax. Cambridge, MA: MIT Press.

[6] Clark, H. H. (1996). Using Language. Cambridge: Cambridge University Press.

[7] Clyne, M. (2000). Lingua franca and ethnolects in Europe and beyond. Sociolinguistica, 14, pp. 83-89.

[8] Coates, J. (2004). Women, Men and Language: A Sociolinguistic Account of Gender Differences in Language (3rd ed.). Harlow, England; New York: Pearson Longman.

[9] Cohen, E. (2001). Thai tourism: Hill tribes, islands and open-ended prostitution (2nd ed.). Bangkok: White Lotus Co. Ltd.

[10] Coronel-Molina, S. M., \& Rodríguez-Mondoñedo, M. (2012). Introduction: Language contact in the Andes and Universal Grammar. Lingua, 122, pp. 447-460.

[11] Delpit, L. (2002). Introduction. In Lisa, D., \& Joanne, K. D. (eds.). The Sking that We Speak: Thoughts on Language and Culture in the Classroom, p. xvii. New York: The New Press.

[12] Draper, J. C. (2004). Isan: The planning context for language maintenance and revitalization. Second Language Learning and Teaching, 4, Electronic document, http://www.usq.edu.au/users/sonjb/sllt/4/Draper04.html, accessed August 14th, 2012.

[13] Draper, J. C. (2010). Inferring ethnolinguistic vitality in a community of Northeast Thailand. Journal of Multilingual and Multicultural Development, 31 (2), pp. 135-147.

[14] Eckert, P. (1997). Gender and sociolinguistic variation. In Coates, J (ed.). Language and Gender: A Reader. pp. 64-75. Malden MA, \& Oxford, UK: Wiley-Blackwell.

[15] Enfield, N. J. (2009). Language and culture. In Li Wei., \& Vivian, C (eds.). Contemporary Applied Linguistics 2. (Linguistics for the Real World). pp. 83-97. London: Continuum.

[16] Ethnologue (2005). Ethnologue: Languages of the World (15th ed). Dallas: SIL International. Retrieved on November $30^{\text {th }}$ 2012 from the Web Site: WWWat http://www.ethnologue.com/web.asp.

[17] Fishman, J. (1964). Language maintenance and language shift as a field of enquiry. Linguistics, 9, pp. 32-70.

[18] Fishman, J. (1965). Who speaks what language to whom and when? La Linguistique, 2, pp. 67-88.

[19] Fishman, J. (1989). The spread of English as a new perspective for the study of language maintenance and language shift. In J. A. Fishman (ed.), Language and Ethnicity in Minority Sociolinguistic Perspective, pp. 32-263. Clevedon: Multilingual Matters.

[20] Fishman, J. (1991). Reversing Language Shift: Theoretical and Empirical Foundations of Assistance to Threatened Languages. Clevedon: Multilingual Matters.

[21] Gagné, I. (2008). Urban princesses: Performance and "women's language" in Japan's Gothic/Lolita subculture. Journal of Linguistic Anthropology, 18 (1), pp. 130-150.

[22] Gal, S. (1978). Peasant men don't get wives: Language and sex roles in a bilingual community. Language in Society, 7 (1), pp. $1-16$.

[23] Gal, S. (1979). Language Shift: Social Determinants of Linguistic Change in Bilingual Austria. New York: Academic Press.

[24] Giles, H., Taylor, D. M., \& Bourhis, R. Y. (1977). Towards a theory of language in ethnic group relations. In Howard, G (ed.), Language, Ethnicity and Intergroup Relations, pp. 307-348. London, Academic Press.

[25] Hall, J. K. (2009). Language learning as discursive practice. In Li Wei., \& Vivian, C (eds.). Contemporary Applied Linguistics 1 (Language Teaching and Learning), pp. 255-274. London: Continuum.

[26] Hill, J. (1987). Women's speech in modern Mexicano. In Philips, S. U., Steele, S., \& Tanz, C (eds.). Language, Gender, and Sex in Comparative Perspective, pp. 121-160. Cambridge: Cambridge University Press.

[27] Howard, K. M. (2007). Kinterm usage and hierarchy in Thai children's peer groups. Journal of Linguistic Anthropology, 17 (2), pp. 204-230.

[28] Hutchison, N. (2002). A fool in paradise. Tumbi Umbi, NSW: Mitraphab Centre Pty Ltd.

[29] Hymes, D. (1974). Foundations in Sociolinguistics: An Ethnographic Approach. Philadelphia: University of Pennsylvania Press. 
[30] Jaspers, J. (2008). Problematizing ethnolects: Naming linguistic practices in an Antwerp secondary school. International Journal of Bilingualism, 12 (1\&2), pp. 85-103.

[31] Kosonen, K. (2008). Literacy in local languages in Thailand: Language maintenance in a globalized world. International Journal of Bilingual Education and Bilingualism, 11 (2), pp. 170-188. Bristol, Multilingual Matters.

[32] Lake, M., \& K. Schirbel. (2000). Love, Sex and Trust: Romantic Adventures in Thailand. Phuket: Meteve Phuket Co. Ltd.

[33] Landry, R., \& Bourhis, R. Y. (1997). Linguistic landscape and ethnolinguistic vitality: An empirical study. Journal of Language and Social Psychology, 16, pp. 23-49.

[34] Manzanares, J., \& Kent, D. (2006). Only 13: The True Story of Lon. Bangkok, Thailand: Bamboo Sinfonia Publications.

[35] Pack, S. (2011). "Where men can be men": Resituating Thai masculinity. Asian Social Science, 7 (9), pp. 3-8. Canadian Center of Science and Education.

[36] Perve, E., \& C. Robinson. (2007). Love in the Land of Smiles. Chiang Mai: Alligator Service Co., Ltd.

[37] Poon, A. (1993). Tourism, Technology and Competitive Strategies. Wallingford: CAB International.

[38] Przeclawski, K. (1993). Tourism as the subject of interdisciplinary research. In D.G. Pearce \& R.W. Butler (eds.). Tourism Research, pp. 9-19. London: Routledge.

[39] Seabrook, J. (2007). Cities. London: Pluto Press.

[40] Silverstein, M. (1979). Language structure and linguistic ideology. In Paul C., William F. H., \& Carol L. H (eds.). The Elements: A Parasession on Linguistic Units and Levels, pp. 193-247. Chicago: Chicago Linguistic Society.

[41] Smalley,W. A. (1994). Linguistic Diversity and National Unity: Language Ecology in Thailand. Chicago: The University of Chicago Press.

[42] Smith-Hefner, N. J. (2009). Language shift, gender and ideologies of modernity in Central Java, Indonesia. Journal of Linguistic Anthropology, 19 (1), pp. 57-77.

[43] Stearn, D. (2004). Pattaya: Patpong on steroids. Kincumber, NSW: Mitraphab Centre Pty Ltd.

[44] Vallverdú, F. (1985). El fet lingüística com a fet social (6th Ed). Barcelona: Edicions 62.

[45] Vygotsky, Lev. (1978). Mind in Society: The Development of Higher Psychological Processes. Cambridge: Cambridge University Press.

[46] Walker, D., \& R.S. Erlich. (1992). 'Hello my big big honey!'. Bangkok: Dragon Dance Publications.

[47] Wilson, J. D. (2008). Thai bar girls and farang: a customized inter-cultural professional services market. Human Resource Development International, 11 (4), pp. 401-415. London: Roudledge.

[48] Woolard, K. A. (1985). Language variation and cultural hegemony: Toward an integration of linguistic and sociolinguistic theory. American Ethnologist, 12, pp. 738-48.

[49] Woolard, K. A. (1998). Language ideology as a feld of inquiry. In Schieffelin, B. B., Woolard, K., \& Kroskrity, P. (eds.). Language Ideologies: Practice and Theory, pp. 3-49. New York: Oxford University Press.

[50] Woywode, M. (2007). The Intercultural Environment in Thailand. Google search: 'Intercultural environment Thailand' (accessed November 25, 2007).

[51] Young, R. (2009). Discursive Practice in Language Learning and Teaching. Malden MA, \& Oxford, UK: Wiley-Blackwell.

Hugo Yu-Hsiu Lee (b. 1978, Kaohsiung, Taiwan/Formosa) is a language educator for minorities. He is an award-winning researcher in USA (Indiana University) and Thailand (National Institute of Development Administration).

His articles appear in journals such as Journal of Language Teaching and Research (2011), Modern Journal of Applied Linguistics (2011), International Journal of Language, Society and Learning (2011), International Review of Social Sciences and Humanities (2011), Journal of Education and Practice (2012) and proceedings of Foreign Language Learning Teaching (2011), proceedings of Language, Society and Culture in Asian Contexts (2010) and (forthcoming) Journal of Linguistics Anthropology.

$\mathrm{He}$ is currently serving in the editorial review board for the Journal of Language Teaching and Research (JLTR) (housed in Finland), the Journal of Education and Practice (JEP) (housed in New York and London), and the World Journal of English Language (WJEL) (housed in Canada).

He has two Taiwanese parents, an American mother, an American Bible teacher, an academic adviser and mentor from Peru (Andes), a sweet Thai/Siamese wife and a Thai/Siamese baby girl. He divides his time in three countries (Taiwan/Formosa, Thailand/Siam and USA) and calls three great cities/metropolises (Kaohsiung, Bangkok and Bloomington) home. 